12. STANAG 2453/AMedP-3.5: The Extent of Dental And Maxillo-facial Treatment at Role 1-3); 2017. p. 148.

13. STANAG 2464/AMedP-31: Military forensic dental identification; 2014. p. 88.
14. STANAG 2466/AMedP-4.4: Dental Fitness Standards for Military Personnel and a Dental Fitness Classification System; 2014. p. 112.

15. STANAG 2549/AMedP-2.4: Emergency care in the operational environment; 2011. p. 348.

Стаття надійшла до редакції

20.10.2019

UDC 615.331:579.864.1:615.451.1

https://doi.org/10.26641/2307-0404.2020.1.200393

\section{O.V. Knysh, A.V. Martynov}

\title{
POTENTIATION OF THE ANTIMICROBIAL EFFECT OF LACTOBACILLUS REUTERI DSM 17938 CELL-FREE EXTRACTS BY ASCORBIC ACID
}

SI «I. I. Mechnikov Institute of Microbiology and Immunology of National Academy of Medical Sciences of Ukraine» Pushkinska str., 14/16, Kharkiv, 61057, Ukraine ДУ «Інститут мікробіології та імунології імені I. І. Мечникова Національної академії медичних наук Украӥни» вул. Пушкінська, 14/16, Харків, 61057, Україна e-mail:knysh_oksana@ukr.net

Цитування: Медичні перспективи. 2020. Т. 25, № 1. С. 17-24

Cited: Medicni perspektivi. 2020;25(1):17-24

Key words: combinatorial (precursor-directed) biosynthesis, Lactobacillus reuteri DSM 17938 derivatives, modified ascorbic acid, HPLC-analysis

Ключові слова: комбінаторний (спрямований прекурсором) біосинтез, похідні L. reuteri DSM 17938, модифікована аскорбінова кислота, ВЕРХ-аналіз.

Ключевые слова: комбинаторный (направленный прекурсором) биосинтез, производные L. reuteri DSM 17938 , модифицированная аскорбиновая кислота, ВЭЖХ-анализ

Abstract. Potentiation of the antimicrobial effect of Lactobacillus reuteri DSM 17938 cell-free extracts by ascorbic acid. Knysh O.V., Martynov A.V. The purpose of this study was to evaluate the effect of supplementing the culture medium with ascorbic acid on the antimicrobial properties of Lactobacillus reuteri cell-free extracts (CFEs). CFEs were prepared using commercial strain L. reuteri DSM 17938 by culturing lactobacilli in its own disintegrated cell suspension (DCS) supplemented with ascorbic acid in sub-inhibitory (5 $\mathrm{mg} / \mathrm{ml}$, CFE 5 ) or minimal inhibitory concentration $(20 \mathrm{mg} / \mathrm{ml}$, CFE 20$)$ and without supplementation (CFE $)$. Staphylococcus aureus ATCC 25923, Escherichia coli ATCC 25922 reference strains and Pseudomonas aeruginosa extensively drug resistant (XDR) clinical isolate were used as indicator cultures. Screening of the inhibitory properties of the studied CFEs and elucidation of the nature of inhibitory products were done using modified Micro scale Optical Density Assay (MODA). The inhibition indices (InhI) were calculated for the studied CFEs and ascorbic acid of appropriate concentrations. CFEs were subjected to HPLC-analysis. $C F E_{5}$ and $C F E_{20}$ showed significantly higher antimicrobial activity toward to indicator cultures than $C F E_{0}$. InhI calculated for extracts $C F E_{5}$ and $C F E_{20}$ mainly exceeded the sum of the corresponding indicators calculated for $C F E_{0}$ and ascorbic acid (AA) of appropriate concentrations: InhI CFE $E_{5} \geq \operatorname{InhI} C F E_{0}+\operatorname{InhI}$ $A A_{5}$; InhICFE $20>$ InhI CFE + InhI AA 20. Acidic metabolic products have made the greatest contribution to the antimicrobial effect of the studied CFEs. HPLC-nalysis showed that the modified ascorbic acid was the substance found in CFE 20 in the greatest quantity. The revealed effect of potentiation of antimicrobial activity of CFEs by ascorbic acid should be taken into account when developing new biotechnological products based on derivatives of L. reuteri DSM 17938. 
Реферат. Потенціювання протимікробного ефекту безклітинних екстрактів Lactobacillus reuteri DSM 17938 аскорбіновою кислотою. Книш О.В., Мартинов А.В. Метою иъього дослідження було оцінити вплив аскорбінової кислоти в культуральному середовищі на протимікробні властивості безклітинних екстрактів (БКЕ) Lactobacillus reuteri. БКЕ були отримані з використанням штаму L. reuteri DSM 17938 шляхом культивування лактобактерій у дезінтегрованій суспензї власних клітин без додавання (БКЕ додаванням аскорбінової кислоти в субінгібіторній (5 мг/мл, БКЕ 5 ) або мінімальній інгібіторній концентрації (20 мг/мл, БКЕ 20$)$. Референтні штами Staphylococcus aureus ATCC 25923, Escherichia coli ATCC 25922 ma клінічний ізолят Pseudomonas aeruginosa з широкою лікарською стійкістю були використані як індикаторні культури. Скринінгове дослідження інгібіторних властивостей досліджуваних БКЕ та з'ясування природи інгібіторних продуктів проводили з використанням модифікованого спектрофотометричного мікропланшетного методу. Інгібіторні індекси (ІнгІ) розраховували для дослідних БКЕ та аскорбінової кислоти відповідних концентрацій. БКЕ піддавали ВЕРХ-аналізу. БКЕ активність по відноченню до індикаторних культур, ніж БКЕ. ІнгІ, розраховані для БКЕ переважно перевищували суми аналогічних показників, розрахованих для БКЕ

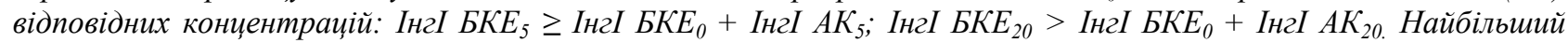
внесок у протимікробний ефект дослідних БКЕ належав кислим продуктам метаболізму. ВЕРХ-аналіз показав, щчо в БКЕ 20 у найбільшій кількості містилася модифікована аскорбінова кислота. Виявлений ефект посилення аскорбіновою кислотою протимікробної активності БКЕ слід ураховувати при розробці нових біотехнологічних продуктів на основі похідних L. reuteri DSM 17938.

The wide spread of antibiotic resistance among bacteria dictates the need to change the strategy and tactics of combating diseases of an infectious nature. Promising direction is the development of etiopathogenetic agents with a wide spectrum of action (antimicrobial, immunotropic and anti-inflammatory). Currently, probiotics are considered as an alternative to classic antibacterial agents [1]. In addition, there are evidences of their anti-inflammatory and immunomodulatory effects $[9,12]$. Most of the beneficial effects of probiotics are due to the biological activity of cell structural components and metabolic products $[12,14]$. For the implementation of the probiotic action, the colonization of a certain biotope by probiotic cells and the time for their activation are required. However, during transit through the gastrointestinal tract, significant cell loss occurs. This is the main reason for the lack of effectiveness of cell probiotics [4].

Probiotic bacteria can be considered as a valuable source of postbiotic products (metabiotics). They are ready-made biologically active structural components and/or metabolites, the effects of which can be realized immediately after introduction. In addition, they make it possible to avoid undesirable effects associated with the introduction of whole cells [14].

Lactobacillus reuteri is one of the important probiotic bacteria capable of exerting antimicrobial, immunomodulatory and anti-inflammatory effects in the host organism. It can produce a number of antimicrobial substances [9]. There are conflicting data regarding the antimicrobial activity of cell-free supernatants obtained from the L. reuteri culture. Some authors have shown that the supernatant of $L$. reuteri exhibits the lowest antimicrobial activity compared to the supernatants of other probiotic lactobacilli [3]. Other authors have stated the high antibacterial potential of the supernatants of four $L$. reuteri strains. They argue that the antimicrobial potential is determined by the profile of the produced metabolites in specific cultivation conditions [2]. Certain probiotic L. reuteri strains have the ability to convert of glycerol into a broad-spectrum antimicrobial compound reuterin. Moreover, L. reuteri has the most pronounced ability to produce this aldehyde and the least sensitivity to it compared to other microorganisms. The production of reuterin is an example of a precursor-directed antimicrobial biosynthesis [10]. Nowadays, the precursor-directed biosynthesis is considered as one of the three major strategies for combinatorial biosynthesis and a promising way to obtain antimicrobial and anticancer agents [10, 13]. Enzymelevel modification and pathway-level recombination are no less promising classical approaches for combinatorial biosynthesis of multiple natural product analogs [13].

Ascorbic acid is an organic compound known for its high reducing potential and ability to regulate oxidation-recovery processes. Recent studies indicate the ability of ascorbic acid to inhibit the growth and biofilm formation by opportunistic and pathogenic bacteria [11, 16]. Limited evidence exists regarding the role of ascorbic acid as a precursor to biologically active metabolites of living organisms.

The purpose of this study was to evaluate the effect of supplementing the culture medium with ascorbic acid on the antimicrobial properties of $L$. reuteri cell-free extracts.

\section{MATERIALS AND METHODS OF RESEARCH}

Cell-free extracts (CFEs) were prepared using commercial strain L. reuteri DSM 17938 (from medical product "BioGaia", BioGaia Production AB, Sweden). 
Obtaining of CFEs was performed as described previously with slight modifications [7].

Preparation of disintegrated cell suspension (DCS). The suspension of $L$. reuteri in isotonic saline solution $(0.9 \% \mathrm{NaCl})$ corresponding optical density of 10 units on the McFarland scale $\left(\sim 10^{8}\right.$ $\mathrm{CFU} / \mathrm{ml}$ ) was subjected to 10 cycles of slow freezing-thawing. Freezing of $50 \mathrm{~mL}$ samples was carried out to $-23^{\circ} \mathrm{C}$. Then samples were heated in a water bath at a temperature of $37^{\circ} \mathrm{C}$ until completely thawed. The obtained DCSs were divided into three portions. The first portion of them was retained without additives. The second and third portions were supplemented with ascorbic acid (PA, Sigma) in a final concentration of $5 \mathrm{mg} / \mathrm{ml}$ and $20 \mathrm{mg} / \mathrm{ml}$.

Cultivation of $L$. reuteri in DCS. The suspension of $L$. reuteri in isotonic saline solution $\left(\sim 10^{8} \mathrm{CFU} / \mathrm{ml}\right)$ was inoculated into DCS (supplemented and not supplemented with ascorbic acid) at a ratio of $1: 9$ and was cultured at $37^{\circ} \mathrm{C}$ for 72 hours.

Preparation of CFEs. The cultures obtained by cultivating of $L$. reuteri in DCS were centrifuged at $3000 \mathrm{~g}$ for $10 \mathrm{~min}$. Cell free supernatants were passed through membrane filters (Vladipor, Russian Federation) with a pore diameter of $0.2 \mu \mathrm{m}$ to remove microbial cells and cellular debris. Thus, three types of extracts were obtained from $L$. reuteri cultured in DCS: 1) without supplementation $\left(\mathrm{CFE}_{0}\right)$; 2) supplemented with acsorbic acid, $5 \mathrm{mg} / \mathrm{ml}\left(\mathrm{CFE}_{5}\right)$ and 3) supplemented with acsorbic acid, $20 \mathrm{mg} / \mathrm{ml}$ $\left(\mathrm{CFE}_{20}\right)$.

Indicator strains. Reference strains: Staphylococcus aureus ATCC 25923, Escherichia coli ATCC 25922 and Pseudomonas aeruginosa extensively drug resistant (XDR) clinical isolate were used as indicator cultures.

Preparation of the inoculum. After verifying the purity of the indicator culture, few colonies from the overnight incubated agar medium were emulsified in a physiological saline for obtaining a suspension corresponding optical density of 0.5 units on the McFarland scale. Then the suspension was diluted ten times.

Inhibitory properties. Screening of the inhibitory properties of the studied CFEs and elucidation of the nature of inhibitory products were carried out using Micro scale Optical Density Assay (MODA) described by Lash et al. with some modifications [8].

Screening of the inhibitory properties. Briefly, the optical density gain of indicator bacteria in the liquid nutrient broth for $24 \mathrm{~h}$ at $37^{\circ} \mathrm{C}$ was compared in the presence (test sample) or absence (control sample) of the studied CFEs and ascorbic acid in appropriate concentrations. The ratio of the nutrient broth, inoculum and CFE (or ascorbic acid) in the incubation medium was $6: 1: 3$, respectively. The optical density was measured using a microtiterplate reader «Lisa Scan EM» («Erba Lachema s.r.o.», Czech Republic) at $578 \mathrm{~nm}$. The growth inhibition indices (InhI) were calculated by the formula: $\quad$ InhI $=\left(\Delta \mathrm{OD}-\Delta \mathrm{OD}_{\mathrm{PC}}\right) \div \Delta \mathrm{OD}_{\mathrm{PC}} \times 100 \%$, where $\Delta \mathrm{OD}$ and $\Delta \mathrm{OD}_{\mathrm{PC}}$ were the changes in the optical density of the control and test samples within 24 hours [7].

Elucidation of the nature of inhibitory products. Two types of CFEs from $L$. reuteri cultured in DCS: 1) without supplementation and 2) supplemented with acsorbic acid $(20 \mathrm{mg} / \mathrm{ml})$ were divided into equal portions for different assays. One portion was retained as untreated. The second portion was treated with proteolytic enzyme pepsin $(1 \mathrm{mg} / \mathrm{ml}$, Sigma) for elucidate the contribution of the proteinaceous component to inhibitory activity of CFEs. For determination of a contribution of organic acids the third portion was adjusted to $\mathrm{pH}$ 6.8-7 using $1 \mathrm{~N} \mathrm{NaOH}$. The fourth portion after neutralization was treated with catalase $(0.5 \mathrm{mg} / \mathrm{ml}$, Sigma $)$ at $25^{\circ} \mathrm{C}$ for $1 \mathrm{~h}$ to determine the contribution of hydrogen peroxide to the inhibitory activity. The fifth portion after neutralization was treated with proteolytic enzyme trypsin $(1 \mathrm{mg} / \mathrm{ml}$, Sigma $)$ at $37^{\circ} \mathrm{C}$ for $2 \mathrm{~h}$ to find out the possible inhibitory effect of substances of a proteinaceous nature. The optical density gain of indicator bacteria in the presence of untreated and treated CFEs was determined as described above.

Chromatographic study was performed according to the procedure described previously [15]. Acetonitrile (Sigma, USA) and lithium perchlorate, perchloric acid in a kit for chromatograph BD2003 (Econova, RF) were used for HPLC-analysis. For analysis of experimental substrates was used HPLCsystem Milichrome A-02 (Econova, RF). In addition, we used a set of chromatography conditions for analysis of riboflavin derivatives: gradient separation of acetonitrile (from $0 \%$ to $100 \%$ ) / $0.05 \mathrm{M}$ lithium perchlorate buffer $+0.01 \mathrm{M}$ perchloric acid at $40^{\circ} \mathrm{C}$, and fraction detection in UV region. As a comparison, we used ascorbic acid.

Statistical analysis. All experiments were performed three times in triplicate. Obtained data were statistically processed using Windows ${ }^{\circledR}$ XP Professional OEM Software, Excel 2003 (license No 74017-640-0000106-57973). Average values of obtained indices with standard deviations were determined $(\mathrm{x} \pm \mathrm{SD})$. One-way analysis of variance (ANOVA) was performed followed post hoc multiple comparison using Bonferroni adjustment and critical value of $p$ equaled to $0.05 /$ (number of possible comparisons) [6]. 
RESULTS AND DISCUSSION

Screening of the inhibitory activity of the studied CFEs. The growth inhibition indices presented in the Table indicate that the strongest decrease of the optical density gain of indicator cultures occurred under the influence of CFEs obtained by culturing L. reuteri in DCS supplemented with ascorbic acid $\left(\mathrm{CFE}_{5}\right.$ and $\left.\mathrm{CFE}_{20}\right)$. More pronounced inhibition was observed with the addition of ascorbic acid at a higher concentration (InhI $\mathrm{CFE}_{20}>\mathrm{InhI} \mathrm{CFE}_{5}$ ). It should be noted that the InhIs calculated for extracts $\mathrm{CFE}_{5}$ and $\mathrm{CFE}_{20}$ mainly exceeded the sum of the corresponding indicators calculated for $\mathrm{CFE}_{0}$ and ascorbic acid (AA): InhI $\mathrm{CFE}_{5} \geq \operatorname{InhI} \mathrm{CFE}_{0}+\operatorname{InhI} \mathrm{AA}_{5} ;$ InhI $\mathrm{CFE}_{20}>$ InhI $\mathrm{CFE}_{0}+\mathrm{InhI} \mathrm{AA}_{20}$. Among the studied indicator cultures, the least inhibitory effect of $\mathrm{CFE}_{0}$ and ascorbic acid was observed toward to $P$. aeruginosa (XDR). $\mathrm{CFE}_{20}$ inhibited the growth of all studied indicator cultures to the same extent.

\section{Inhibitory activity of cell-free extracts (CFEs) and ascorbic acid (AA) against indicator cultures}

\begin{tabular}{c|c|c|c|c|c}
\hline \multirow{2}{*}{ Indicator strains } & \multicolumn{5}{|c}{ InhIs, \% (x \pm SD) } \\
\cline { 2 - 6 } & $\mathrm{CFE}_{0}$ & $\mathrm{CFE}_{5}$ & $\mathrm{CFE}_{20}$ & $\mathrm{AA}_{5}$ & $\mathrm{AA}_{20}$ \\
\hline S. aureus ATCC 25923 & $53.2 \pm 5$ & $\mathbf{8 0 . 4} \pm 7^{*}$ & $\mathbf{9 0 . 9} \pm 8^{*}$ & $22.9 \pm 2$ & $38.5 \pm 5$ \\
E. coli ATCC 25922 & $34.7 \pm 6$ & $63.3 \pm 4^{*}$ & $96.0 \pm 4^{*}$ & $17.5 \pm 5$ & $30.0 \pm 6$ \\
P. aeruginosa (XDR) & $26.5 \pm 5$ & $85.2 \pm 5^{*}$ & $93.0 \pm 7^{*}$ & $0.1 \pm 3$ & $2.4 \pm 2$ \\
\hline
\end{tabular}

Notes. ${ }^{*}-$ the differences are statistically significant With respect to the inhibition indices calculated for $\mathrm{CFE}_{0}$ and $\mathrm{AA}$ of appropriate concentration, $p<0.05$.

Elucidation of the nature of inhibitory products. The data presented in Fig. 1 show that $\mathrm{CFE}_{0}$ treated with pepsin significantly inhibited the growth of both indicator cultures: $S$. aureus and E. coli. InhI were $45.2 \%$ and $31.2 \%$, respectively. $\mathrm{CFE}_{0}$ after neutralization and treatment with trypsin and catalase did not significantly affect the optical density gain of both indicator cultures. An exception was S. aureus: the InhI of culture under the influence of $\mathrm{CFE}_{0}$ treated only with $\mathrm{NaOH}$ was $10.6 \%$. Thus, the study revealed that the contribution of the proteinaceous component to the inhibitory activity of the $\mathrm{CFE}_{0}$ against $S$. aureus was small, and against $E$. coli it was negligible.

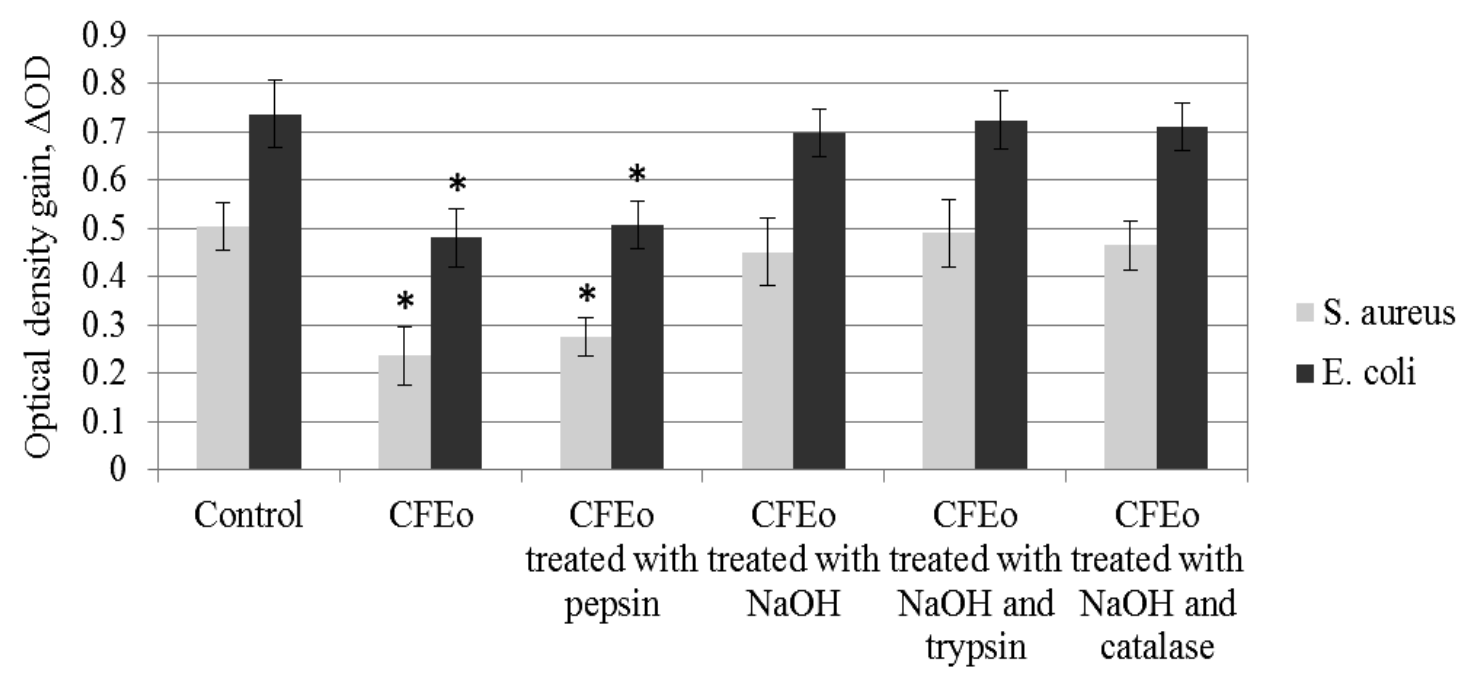

Notes. ${ }^{*}$ - the differences are statistically significant with respect to the control indices, $p<0.05$

Fig. 1. The effect of treated and untreated $\mathrm{CFE}_{0}$ on the growth of indicator cultures 
As can be seen from the data presented in Fig. 2, pepsin-treated $\mathrm{CFE}_{20}$ reduced the optical density gain of staphylococcal culture by $81.8 \%$. InhI calculated for pepsin-treated $\mathrm{CFE}_{20}$ toward E. coli was $91.2 \%$. Neutralization led to a significant decrease in antimicrobial activity of $\mathrm{CFE}_{20}$. InhI calculated for $\mathrm{CFE}_{20}$ treated with $\mathrm{NaOH}$ toward $S$. aureus was $13.6 \%$, and toward E. coli it was $10.2 \%$. Optical density gain of both cultures under the influence of neutralized $\mathrm{CFE}_{20}$ treated with trypsin or catalase did not significantly differ from the benchmarks. This indicated an almost complete loss of antimicrobial activity of the $\mathrm{CFE}_{20}$ after neutralization and treatment with enzymes.

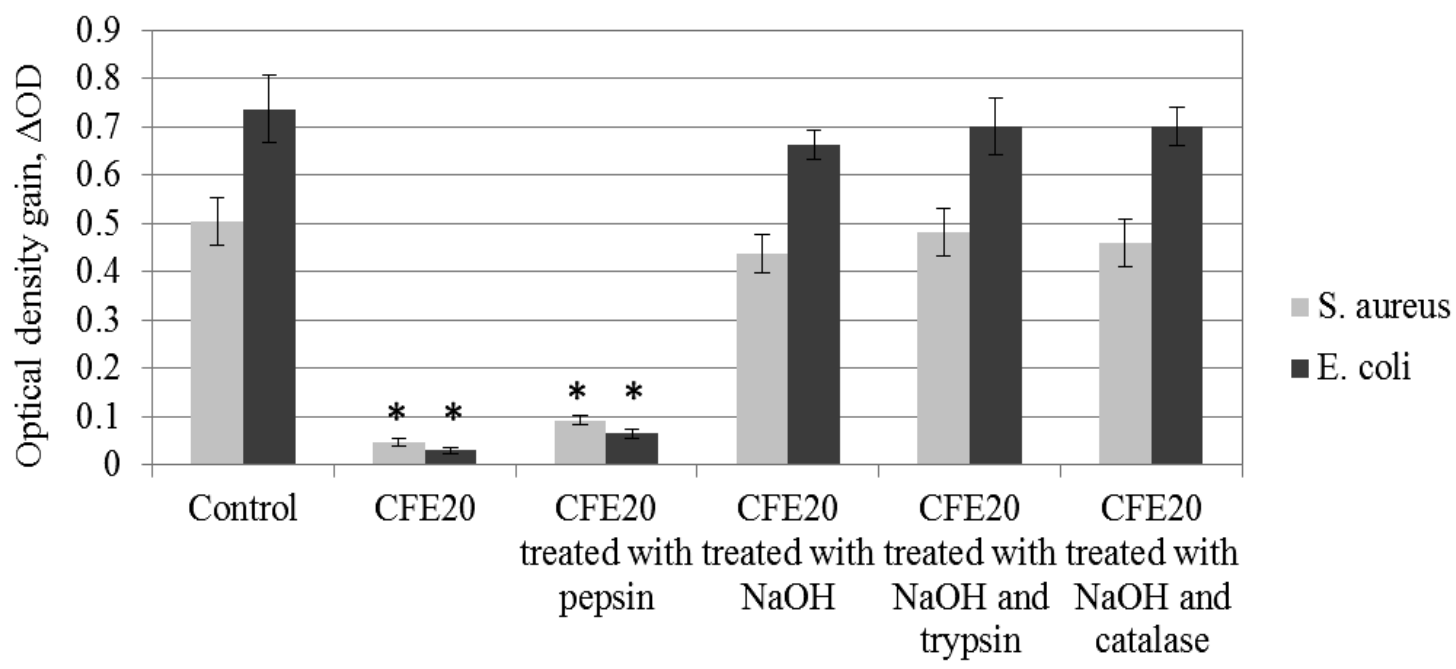

Notes. ${ }^{*}$ - the differences are statistically significant with respect to the control indices, $p<0.05$

Fig. 2. The effect of treated and untreated $\mathrm{CFE}_{20}$ on the growth of indicator cultures

Chromatographic study. Fig. 3 shows the HPLCchromatogram of degradation products / ascorbic acid as result of ascorbic acid modification by $L$. reuteri. The greatest quantity of the substance in the $\mathrm{CFE}_{20}$ is modified ascorbic acid. Although UVSpectrum (peak 1) is like ascorbic acid, but retention time of (peak 1) is shifted in a hydrophobic region. This indicates that the substance (peak 1) is a modified product derived as a result of the ascorbic acid conversion by L. reuteri, alike as this bacterium converts glycerol to reuterin.

There are a number of mechanisms for the antimicrobial action of probiotics. Different strains of $L$. reuteri can produce and excrete a variety of antimicrobial molecules: lactic acid, acetic acid, ethanol, hydrogen peroxide, carbon dioxide, diacetyl, bacteriocin (reutericin 6), reutericyclin and reuterin $[2,9,10]$. However, there is no evidence that single strain can produce reutericin, reutericycin, reuterin, or two of these antimicrobial compounds simultaneously. Bacteriocin has a peptide nature; therefore, it loses its activity after treatment with proteolytic enzymes or after prolonged heat treatment. Its production is highly dependent on the cultivation conditions. Reute- ricycline is a tetramic acid molecule that functions as a proton ionophore and dissipates the transmembranic $\Delta \mathrm{pH}$. It exhibits a powerful antimicrobial effect against Gram-positive microorganisms in low concentrations. The toxicity of reutericycline to humans and animals remains unstudied.

As mentioned earlier, L. reuteri has the ability to convert glycerol into a broad-spectrum antimicrobial compound reuterin. For adequate antimicrobial activity of $L$. reuteri, glycerol is required in amounts significantly exceeding those usually available in the gastrointestinal tract. Therefore, the intake of probiotic bacteria L. reuteri requires additional administration of glycerol [5]. A lot of work has been devoted to confirming the antimicrobial activity of reuterin in vitro, but there are no works demonstrating its antimicrobial activity in vivo. This aldehyde is resistant to proteolytic and lipolytic cleavage. In aqueous solution, reuterine is a threecomponent dynamic system consisting of various (monomeric, hydrated monomeric, and cyclic dimeric) forms of 3-hydroxypropionaldehyde (3HPA) and can be reversibly dehydrated into the toxic acrolein. Therefore, the toxicity and stability of 3-HPA should be fully studied before its use in vivo. 


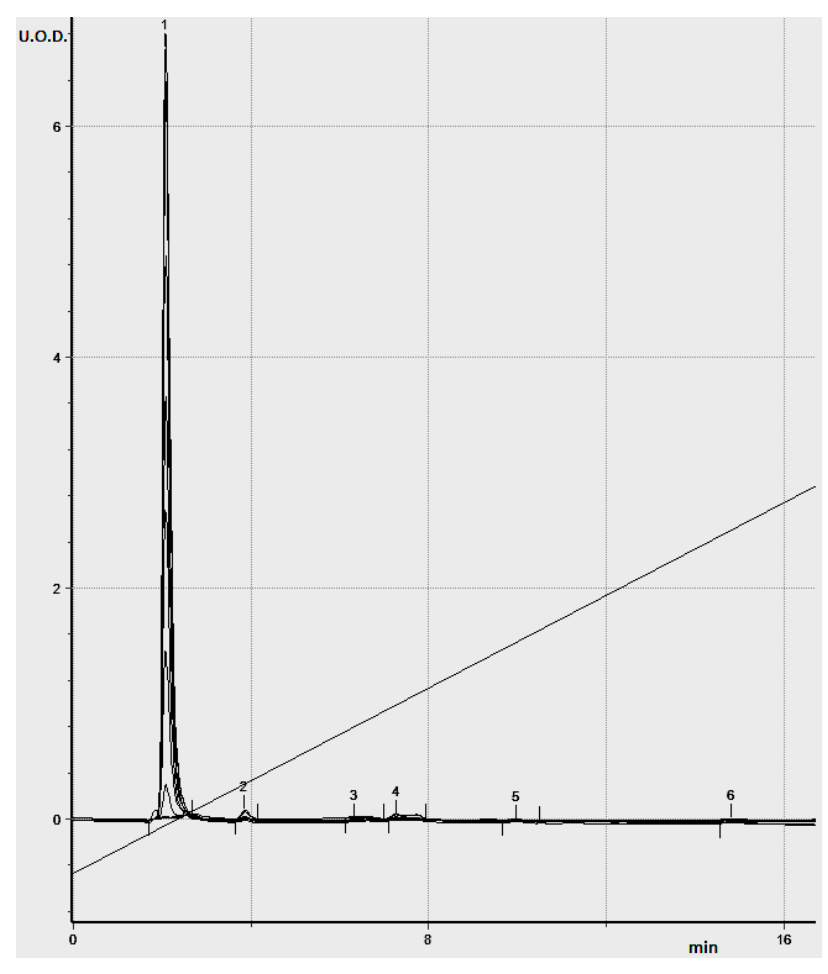

Fig. 3. HPLC-analysis of $\mathrm{CFE}_{20}$.

Analysis of the available data suggests the need to study the role of other important metabolic substances of L. reuteri. Precursor-directed antimicrobial biosynthesis strategy is considered one of the most promising in the development of nextgeneration probiotics [10]. This strategy served as the basis for the search for new precursors.

Well-known biological functions of ascorbic acid are related to its chemical properties as a reducing agent. Recently, there has been an interest in ascorbic acid as an antimicrobial agent. Some of studies have demonstrated the antimicrobial activity of ascorbic acid against Gram-positive, Gramnegative bacteria and fungi $[11,16]$. Different sensitivity of bacteria to ascorbic acid was revealed: non-acid resistant bacteria were sensitive to the dissociated form; the lactobacilli were more sensitive to the non-dissociated form. Important conclusion was made that the sensitivity of microorganisms did not depend on sensitivity to antibiotics. Based on their own observations, the authors expressed doubt that the antibacterial activity of ascorbic acid is associated only with acidification or a decrease in $\mathrm{pH}$. They suggested that ascorbic acid has a specific effect on the cell membrane or cell enzymes [11].

The present study showed that the supplementation of culture medium with ascorbic acid leads to potentiation of the antimicrobial effect of CFEs obtained from the $L$. reuteri culture. The potentiating effect of ascorbic acid was depend on the concentration and did not depend on the indicator culture. It should be noted that ascorbic acid was added to the culture medium in subinhibitory and minimal inhibitory concentrations. The choice of these concentrations was based on data previously obtained by other authors in determining the minimal inhibitory concentrations of ascorbic acid for pathogenic, opportunistic bacteria and lactobacilli (L. plantarum) $[11,16]$.

The results of this study confirmed that the greatest contribution to the antimicrobial effect of CFEs was made by organic acids provided a low $\mathrm{pH}$ level. Neutralization of CFSs led to complete loss of antimicrobial activity or their inhibitory activity toward test bacteria became negligible. The contribution of the proteinaceous component to the antimicrobial activity of $\mathrm{CFE}_{20}$ was little or insignificant.

Chromatographic studies showed that during $L$. reuteri cultivation in presence ascorbic acid in subinhibitory and minimal inhibitory concentrations observed chemical changes in molecular structure of ascorbic acid. This modification leads to potentiation of the inhibitory effects of CFEs toward to indicator cultures.

\section{CONCLUSIONS}

1. Ascorbic acid in sub-inhibitory and minimal inhibitory concentrations potentiates the antimicrobial activity of L. reuteri DSM 17938 CFEs against reference strains: S. aureus ATCC 25923, E. coli ATCC 25922 and P. aeruginosa XDR clinical isolate in vitro.

2. The results of this study show that acidic metabolic products make the largest contribution to the antimicrobial effect of the studied CFEs.

3. The revealed effect of potentiation of the antimicrobial activity of CFEs by ascorbic acid should be taken into account when developing new biotechnological products based on derivatives of $\mathrm{L}$. reuteri DSM 17938.

Conflict of interest. The author declares no conflict of interest

\section{REFERENCES}

1. Czaplewski L, Bax R, Clokie M, Dawson M, Fairhead H, et al. Alternatives to antibiotics - a pipeline portfolio review. Lancet Infect Dis. 2016;16(2):239-51. doi: http://dx.doi.org/10.1016/s1473-3099(15)00466-1
2. Greifová G, Májeková $\mathrm{H}$, Greif G, Body $\mathrm{P}$, Greifová M, Dubničková M. Analysis of antimicrobial and immunomodulatory substances produced by heterofermentative Lactobacillus 
reuteri. Folia Microbiol. 2017;62(6):515-24. doi: http://dx.doi.org/10.1007/s12223-017-0524-9

3. Stefania DM, Miranda P, Diana M, Claudia Z, Rita P, Donatella P. Antibiofilm and antiadhesive activities of different synbiotics. J Probiotics Health. 2017;5(3):1000182.

doi: http://dx.doi.org/10.4172/2329-8901.1000182

4. Navarro JB, Mashburn-Warren L, Bakaletz LO, Bailey MT, Goodman SD. Enhanced probiotic potential of Lactobacillus reuteri when delivered as a biofilm on dextranomer microspheres that contain beneficial cargo. Front Microbiol. 2017;8:489.

doi: http://dx.doi.org/10.3389/fmicb.2017.00489

5. Etchebehere MC, Piveta C, Levy CE. The influence of glycerol upon L. reuteri activity against enteropathogens. Medical Express. 2017;4(6). doi: http://dx.doi.org/10.5935/medicalexpress.2017.06.06

6. Glantz SA. Primer of biostatistics. 7th ed. New York: McGraw-Hill; 2012. p. 327

7. Knysh OV, Isayenko OY, Voyda YV, Kizimenko OO, Babych YM. Influence of cell-free extracts of Bifidobacterium bifidum and Lactobacillus reuteri on proliferation and biofilm formation by Escherichia coli and Pseudomonas aeruginosa. Regul Mech Biosyst. 2019;10(2):251-6. doi: http://dx.doi.org/10.15421/021938

8. Lash BW, Gourama H, Mysliwiec TH. Microscale assay for screening of inhibitory activity of Lactobacillus. BioTechniques. 2002;33(6):1224-8. doi: http://dx.doi.org/10.2144/02336bm08

9. Mu Q, Tavella VJ, Luo XM. Role of Lactobacillus reuteri in human health and diseases. Front Microbiol. 2018;9:757.

doi: http://dx.doi.org/10.3389/fmicb.2018.00757

10. Spinler JK, Auchtung J, Brown A, Boonma P, Oezguen N, Ross CL, et al. Next-generation probiotics targeting Clostridium difficile through precursordirected antimicrobial biosynthesis. Infect Immun. 2017;85(10):e00303-17.

doi: http://dx.doi.org/10.1128/iai.00303-17

11. Panda L. Antibacterial activity of ascorbic acid: $\mathrm{pH}$ effect, specific action or both? In abstracts of papers of the American chemical society (Vol. 255). 1155 16TH ST, NW, Washington, DC 20036. USA: Amer Chemical Soc; 2018.

doi: http://dx.doi.org/10.13140/RG.2.2.22321.48482

12. Piqué N, Berlanga M, Miñana-Galbis D. Health Benefits of Heat-Killed (Tyndallized) Probiotics: An Overview. Int J Mol Sci. 2019;20(10):2534. doi: http://dx.doi.org/10.3390/ijms20102534

13. Ang EL, Sun H, Liu Z, Zhao H. Recent advances in combinatorial biosynthesis for drug discovery. Drug Des Devel Ther. 2015;823. doi: http://dx.doi.org/10.2147/dddt.s63023

14. Singh A, Vishwakarma V, Singhal B. Metabiotics: The Functional Metabolic Signatures of Probiotics: Current State-of-Art and Future Research PrioritiesMetabiotics: Probiotics Effector Molecules. Advances in Bioscience and Biotechnology. 2018;9(4):147-89. doi: http://dx.doi.org/10.4236/abb.2018.94012

15. Martynov AV, Bomko TV, Farber BS, Nosalskaya TN, Kleyn I. Synthesis of dynamic riboflavin derivatives and the study of their ability to urease photoinactivation. Annals of Mechnikov Institute. 2019;3:44-49. doi: http://doi.org/10.5281/zenodo.3469432.

16. Verghese RJ, Mathew SK, David A. Antimicrobial activity of Vitamin $\mathrm{C}$ demonstrated on uropathogenic Escherichia coli and Klebsiella pneumoniae. J Curr Res Sci Med. 2017;3:88-93 doi: http://dx.doi.org/10.4103/jcrsm.jcrsm_35_17

\section{СПИСОК ЛІТЕРАТУРИ}

1. Alternatives to antibiotics - a pipeline portfolio review / L. Czaplewski et al. Lancet Infect Dis. 2016. Vol. 16, No. 2. P. 239-51.

DOI: http://dx.doi.org/10.1016/s1473-3099(15)00466-1

2. Analysis of antimicrobial and immunomodulatory substances produced by heterofermentative Lactobacillus reuteri / G. Greifová et al. Folia Microbiol. 2017. Vol. 62, No. 6. P. 515-24. DOI: http://dx.doi.org/10.1007/s12223017-0524-9

3. Antibiofilm and antiadhesive activities of different synbiotics / D. M. Stefania et al. JProbiotics Health. 2017. Vol. 5, No. 3. P. 1000182. DOI: http://dx.doi.org/10.4172/2329-8901.1000182

4. Enhanced probiotic potential of Lactobacillus reuteri when delivered as a biofilm on dextranomer microspheres that contain beneficial cargo / J. B. Navarro et al. Front Microbiol. 2017. Vol. 8. P. 489. DOI: http://dx.doi.org/10.3389/fmicb.2017.00489

5. Etchebehere M. C., Piveta C., Levy C. E. The influence of glycerol upon L. reuteri activity against enteropathogens. Medical Express. 2017. Vol. 4, No. 6. DOI: http://dx.doi.org/10.5935/medicalexpress.2017.06.06
6. Glantz S. A. Primer of biostatistics. New York: McGraw-Hill, 2012. 327 p.

7. Influence of cell-free extracts of Bifidobacterium bifidum and Lactobacillus reuteri on proliferation and biofilm formation by Escherichia coli and Pseudomonas aeruginosa / O. V. Knysh et al. Regul Mech Biosyst. 2019. Vol. 10, No. 2. P. 251-256.

DOI: http://dx.doi.org/10.15421/021938

8. Lash B. W., Gourama H., Mysliwiec T. H. Microscale assay for screening of inhibitory activity of Lactobacillus. BioTechniques. 2002. Vol. 33, No. 6. P. 122412288. DOI: http://dx.doi.org/10.2144/02336bm08

9. Mu Q., Tavella V. J., Luo X. M. Role of Lactobacillus reuteri in human health and diseases. Front Microbiol. 2018. No 9. P. 757.

DOI: http://dx.doi.org/10.3389/fmicb.2018.00757

10. Next-generation probiotics targeting Clostridium difficile through precursor-directed antimicrobial biosynthesis / J. K. Spinler et al. Infect Immun. 2017. Vol. 85, No. 10. P. e00303-17. DOI: http://dx.doi.org/10.1128/iai.00303-17 
11. Panda L. Antibacterial activity of ascorbic acid: $\mathrm{pH}$ effect, specific action or both?: In abstracts of papers of the American chemical society. 16TH ST, NW, Washington, DC 20036 USA: Amer Chemical Soc, 2018. Vol. 255. P. 1155.

DOI: http://dx.doi.org/10.13140/RG.2.2.22321.48482

12. Piqué N., Berlanga M., Miñana-Galbis D. Health Benefits of Heat-Killed (Tyndallized) Probiotics: an Overview. Int J Mol Sci. 2019. Vol. 20, No. 10. P. E2534. DOI: http://dx.doi.org/10.3390/ijms20102534

13. Recent advances in combinatorial biosynthesis for drug discovery / E. L. Ang et al. Drug Des Devel Ther. 2015. No. 823.

DOI: http://dx.doi.org/10.2147/dddt.s63023

14. Singh A., Vishwakarma V., Singhal B. Metabiotics: The Functional Metabolic Signatures of Probiotics:
Current State-of-Art and Future Research Priorities-Metabiotics: Probiotics Effector Molecules. Advances in Bioscience and Biotechnology. 2018. Vol. 9, No. 4. P. 147189. DOI: http://dx.doi.org/10.4236/abb.2018.94012

15. Synthesis of dynamic riboflavin derivatives and the study of their ability to urease photoinactivation / A. V. Martynov et al. Annals of Mechnikov Institute. 2019. No. 3. P. 44-49.

DOI: http://doi.org/10.5281/zenodo.3469432.

16. Verghese R. J., Mathew S. K., David A. Antimicrobial activity of Vitamin $\mathrm{C}$ demonstrated on uropathogenic Escherichia coli and Klebsiella pneumoniae. J Curr Res Sci Med. 2017. No. 3. P. 88-93 DOI: http://dx.doi.org/10.4103/jcrsm.jcrsm_35_17

Стаття надійшла до редакції 19.11.2019 